\title{
Seasonal variations of throughfall chemistry in pure and mixed stands of Oriental beech (Fagus orientalis Lipsky) in Hyrcanian forests (Iran)
}

\author{
Maryam Salehi ${ }^{1,3} \cdot$ Ghavamudin Zahedi Amiri $^{1} \cdot$ Pedram Attarod $^{1} \cdot$ Ali Salehi $^{2}$. \\ Ivano Brunner ${ }^{3} \cdot$ Patrick Schleppi $^{3} \cdot$ Anne Thimonier $^{3}$
}

Received: 10 June 2015 / Accepted: 22 September 2015 /Published online: 12 October 2015

(C) INRA and Springer-Verlag France 2015

\begin{abstract}
- Key message Throughfall nutrient fluxes were generally higher in a mixed stand than in a pure stand of Oriental beech. Throughfall fluxes were higher than bulk precipitation fluxes except for nitrogen and indicate higher canopy uptake of this element in the pure stand compared to the mixed stand.

- Context Oriental beech is an economically relevant tree species for Iran and adjacent countries. Yet little is known about nutrient cycling in Oriental beech stands and the influence of the degree of mixture with other species.
\end{abstract}

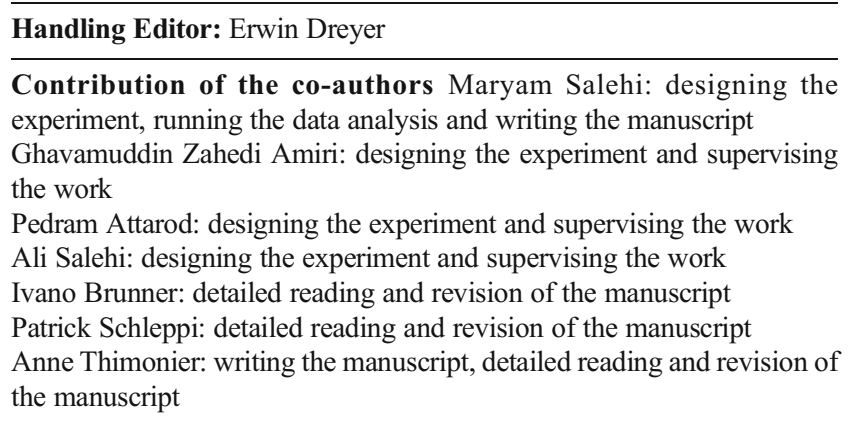

- Aims We assessed the effect of seasons on nutrient fluxes in precipitation and whether throughfall chemistry differed between pure and mixed stands.

- Methods Bulk precipitation in the open field and throughfall were sampled during one whole month within each season from August 2013 to May 2014 in a pure ( $81 \%$ of beech trees on average) and a mixed stand (57 \% of beech trees) of Oriental beech. Samples were analysed for $\mathrm{pH}$, nitrate $\left(\mathrm{NO}_{3}{ }^{-}\right)$, ammonium $\left(\mathrm{NH}_{4}^{+}\right)$, phosphorus $(\mathrm{P})$, calcium $\left(\mathrm{Ca}^{2+}\right)$, magnesium $\left(\mathrm{Mg}^{2+}\right)$ and potassium $\left(\mathrm{K}^{+}\right)$.

- Results Nutrient concentrations were generally higher in the growing season than in the dormant season, both in bulk precipitation and in throughfall. Nutrient fluxes were higher in fall and these peaks coincided with higher amounts of precipitation. The concentrations and fluxes of $\mathrm{NH}_{4}{ }^{+}, \mathrm{NO}_{3}{ }^{-}, \mathrm{P}, \mathrm{Ca}^{2+}$, $\mathrm{Mg}^{2+}$ and $\mathrm{K}^{+}$were generally higher in the mixed stand than in the pure stand in all seasons. Compared to the open field, throughfall fluxes were usually higher, except for $\mathrm{NO}_{3}{ }^{-}$and $\mathrm{NH}_{4}{ }^{+}$, indicating direct canopy uptake of nitrogen.

- Conclusion Canopy composition in Oriental beech stands (owing to differences in foliage chemistry) and seasons (owing to differences in precipitation regime and phenological stages) have a significant effect on throughfall nutrient fluxes.

\author{
Ivano Brunner \\ ivano.brunner@wsl.ch \\ Patrick Schleppi \\ patrick.schleppi@wsl.ch
}

1 Department of Forestry and Forest Economics, Faculty of Natural Resources, University of Tehran, Karaj, Alborz, Iran

2 Department of Forestry, Natural Resources Faculty, University of Guilan, Sowme'eh Sara, Guilan, Iran

3 WSL - Swiss Federal Institute for Forest, Snow and Landscape Research, Birmensdorf, Switzerland 
Keywords Throughfall fluxes $\cdot$ Bulk precipitation $\cdot$ Nutrient concentrations $\cdot$ Canopy composition

\section{Introduction}

Forest nutrient cycles are tightly connected to the hydrological cycle, because rainfall and soil water act as the main transportation and solution media (Bhat et al. 2011; Bruijnzeel 1989). Forest canopy has a major impact on soil nutrient availability through the amount and chemical composition of litter and throughfall (Carnol and Bazgir 2013; De Schrijver et al. 2007; Hansen et al. 2009; Prescott 2002). Throughfall is that part of incident precipitation which passes through the forest canopy, either directly in gaps or after interacting with foliage and branches (Parker 1983).

In forest ecosystems, before rain water reaches the forest floor as throughfall or stemflow (i.e. the throughfall fraction that flows down tree stems), the chemical content of rain water is strongly affected by exchanges within tree canopies (Herrmann et al. 2006). Rainwater is thereby influenced by three main processes (Chiwa et al. 2004): (1) the washing of deposits accumulated on the canopy between precipitation events, (2) the leaching of material from internal plant tissues and (3) the uptake by foliage of solutes. Tree species with different foliage properties exhibit different patterns of throughfall water and ion fluxes (Beier et al. 1993; Hansen 1995; Raat et al. 2002; Whelan et al. 1998). Furthermore, as dry deposition is also a function of foliage properties (Lovett 1994), it may cause species-related differences (Hojjati et al. 2009; Rothe et al. 2002).

As opposed to litterfall, throughfall and stemflow add nutrients directly to the available nutrient pool without the interference of any process of decomposition (Abbasian et al. 2014). Atmospheric deposition is difficult to measure directly. However, the nutrient content of throughfall is often used as a measure of deposition for ions that show minimal foliage uptake or leaching (Rothe and Binkley 2001).

In recent years, mixed stands have received growing attention due to their greater biodiversity, ecological stability and their greater productivity in comparison to pure stands (Pretzsch et al. 2010). Few authors, however, have assessed the impact of tree species composition on atmospheric deposition by studying throughfall fluxes both in pure and mixed stands. Berger et al. (2008) compared stands of pure beech, pure spruce and a mixture of beech and spruce and found that nitrogen and sulphur throughfall fluxes were lowest in the beech stand and highest in the spruce stand, while the mixed stand showed intermediate values. In this same study, the leaching of base cations tended to be lowest in the beech stand, intermediate in the mixed stand and highest in the spruce stand. Talkner et al. (2010) found that the throughfall and stemflow fluxes of $\mathrm{K}^{+}, \mathrm{Ca}^{2+}, \mathrm{Mg}^{2+}$ and $\mathrm{PO}_{4}{ }^{3-}$ were higher in mixed deciduous species plots than in pure beech plots due to higher canopy leaching rates in the mixed species plots.

The temperate deciduous forests of northern Iran, known as the Hyrcanian forests (also called Caspian forests), cover about two million hectares in a narrow strip over $800 \mathrm{~km}$ long and 20-70 km wide (Hosseini Ghaleh Bahmani et al. 2012) and encompass different forest types thanks to their 80 tree and shrub species (Sagheb Talebi et al. 2004). Oriental beech (Fagus orientalis Lipsky) is an economically relevant tree species for Iran and adjacent countries. Beech stands in northern Iran are of special concern since Oriental beech is one of the most valuable and important timber species, covering $17.5 \%$ of the surface area and accounting for $30 \%$ of the volume of the industrial forests in Iran (Sagheb Talebi and Eslami 2008).

Forest productivity is limited by the supply of one or more nutrients in almost all forests, and forest nutrition management is a key factor in the management of commercial forests (Rouhi-Moghaddam et al. 2008; Stape et al. 2006). While there are many studies comparing the mineral nutrition and nutrient cycling in beech stands (Berger et al. 2009a; Staelens et al. 2007), most of them have focused on European beech (Fagus sylvatica L.) and information about throughfall chemistry below Oriental beech canopy is still rare (Abbasian et al. 2014; Moslehi et al. 2011). To date, most studies on Oriental beech stands have been restricted to the quantification of interception loss (Ahmadi et al. 2009; Mattaji et al. 2012; Rahmani et al. 2011). Because of the significant lack of data on throughfall chemistry under Oriental beech canopy, our focus in the present study is throughfall chemistry in beech stands in the Caspian forest. We hypothesized that the chemical composition of throughfall differs in the growing season (spring and summer) compared to the dormant season (late fall and winter) and in pure compared to mixed stands of Oriental beech. Our study addresses the impact of tree composition on throughfall chemistry by asking the following questions:

1. Does tree composition in mixed and pure stands affect atmospheric input?

2. Do seasons affect nutrient fluxes in beech stands?

In addition to these specific research questions, owing to the lack of deposition data for this region and these types of stands, we attempted to estimate annual rainfall and throughfall fluxes of the main nutrients for the period July 2013 to June 2014, based on the four monthly fluxes that we measured.

\section{Material and methods}

\subsection{Site description}

This study was conducted from August 2013 to May 2014 in intact natural stands of $F$. orientalis, within the Gorazbon 
district at the Kheyrud Forest Research Station of the University of Tehran, located approximately $7 \mathrm{~km}$ east of Nowshahr, Mazandaran province, northern Iran $\left(36^{\circ} 33^{\prime} \mathrm{N}, 50^{\circ} 33^{\prime} \mathrm{E}\right)$ (Fig. 1). The Gorazbon district covers about 1000 ha and its elevation ranges from 550 to $1380 \mathrm{~m}$ a.s.l. Ground slopes range from 0 to $115 \%$, and the average slope in the whole district is about $15 \%$. This area is dominated by natural temperate forests containing native mixed deciduous tree species such as F. orientalis Lipsky, Carpinus betulus L. and Acer velutinum Boiss. (Jourgholami et al. 2013). The mean annual precipitation is $1146 \mathrm{~mm}$, with the highest amount in October $(200 \mathrm{~mm})$ and the lowest amount in July $(49 \mathrm{~mm})$. Two sample parcels (Fig. 1) were selected within the Gorazbon district, one covered by an almost pure Oriental beech stand (with beech representing $70 \%$ of the standing volume), the other covered by a mixed stand (52\% of standing volume; Table 1).

Both parcels are in the same elevation class (1150$1350 \mathrm{~m}$ a.s.l.) and lie on similar parent material (limestone). Mean tree density and volume were 225 trees $^{-1} \mathrm{a}^{-1}$ and $463 \mathrm{~m}^{3} \mathrm{ha}^{-1}$ standing volume in the mixed stand and 266 trees $\mathrm{ha}^{-1}$ and $500 \mathrm{~m}^{3} \mathrm{ha}^{-1}$ standing volume in the pure stand (Table 1). In each of these two parcels, 30 rectangular plots, $500 \mathrm{~m}^{2}$ each, homogeneous with respect to slope and aspect, were delimited. In addition, four open areas (two in each parcel) were selected for the sampling of gross rainfall (Fig. 2). We studied the seasonal variation of precipitation chemistry in the pure and mixed stands by intensive sampling in midspring, mid-summer, mid-fall and mid-winter at the plots.

\subsection{Bulk precipitation and throughfall measurement}

Precipitation in the open field (bulk precipitation, BP) and throughfall (TF) were sampled during one whole month within each season: in summer (August 2013), fall (November 2013), winter (February 2014) and spring (May 2014). One manual plastic collector, $9 \mathrm{~cm}$ in diameter and $25 \mathrm{~cm}$ in height, was installed in each of the four open areas for bulk precipitation sampling. For the sampling of throughfall, six collectors were installed in each plot. A nylon mesh was placed at the opening of the collectors to prevent contamination by coarse debris. The collectors were emptied twice, in the middle and at the end of the sampling months. In the middle of the sampling month, after sample collection, the collectors were rinsed with distilled water before being replaced. The volumes collected were measured using a graduated cylinder and the contents of the six collectors were pooled in the field to one composite sample per plot, resulting in $2 \times 30$ samples for each collection period. The samples were then taken to the laboratory and stored at $4{ }^{\circ} \mathrm{C}$. One exception to this general procedure concerned the first 2 weeks of February, during which precipitation fell in the form of snow. After the 2-week exposure, the collectors were replaced by clean ones and pooling took place after melting in the laboratory.

The samples of the two collection periods within a month were pooled before analysis to obtain monthly samples. The $\mathrm{pH}$ of the rainfall was measured with a $\mathrm{pH}$ meter. The nitrate $\left(\mathrm{NO}_{3}{ }^{-}\right)$and ammonium $\left(\mathrm{NH}_{4}{ }^{+}\right)$concentrations were measured using the Kjeldahl method. The $\mathrm{NH}_{4}{ }^{+}$fraction in the sample

Fig. 1 The experimental area located at the Forest Research Station of the University of Tehran, Iran

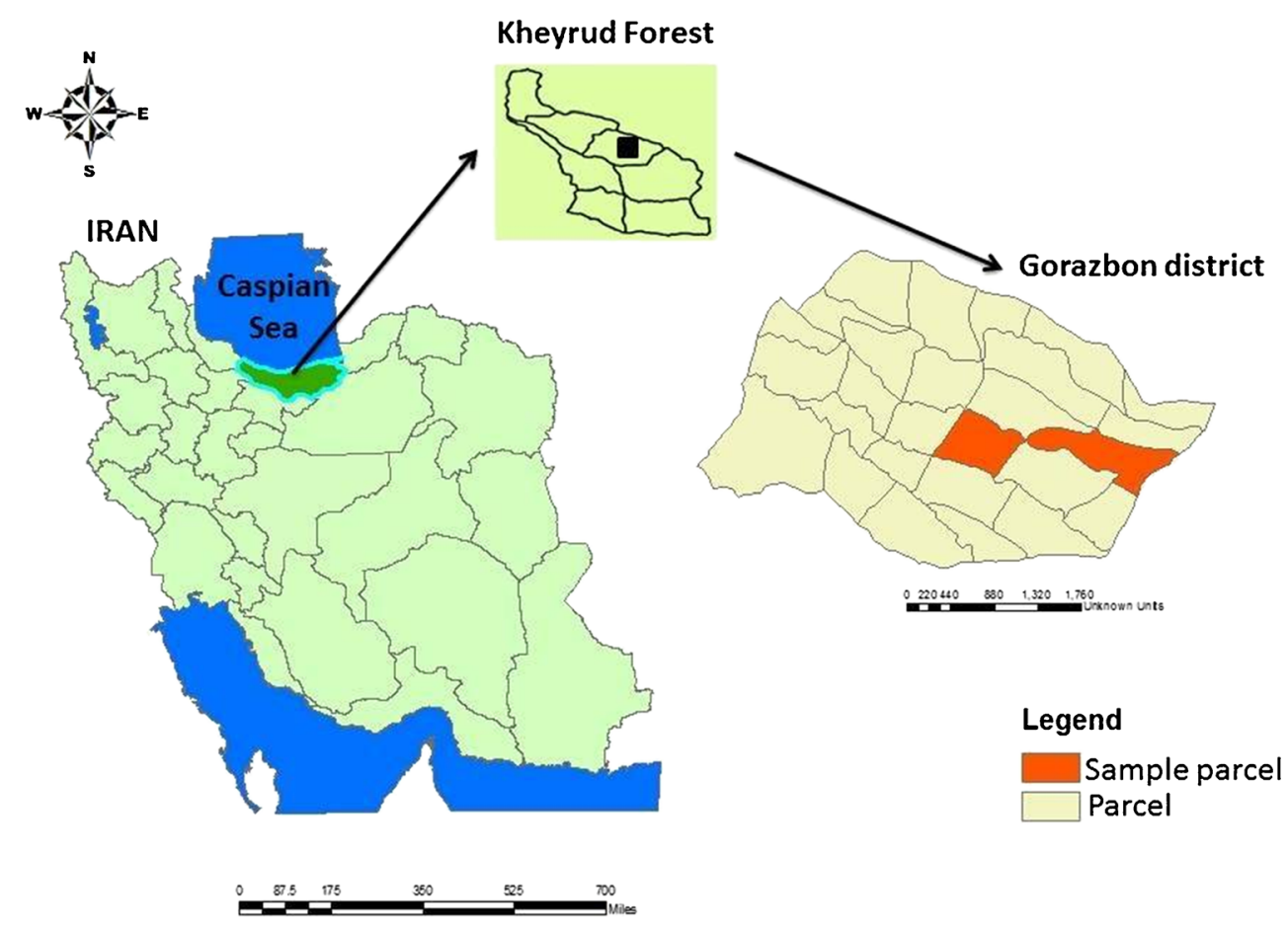


Table 1 Stand characteristics in the two forest parcels in which the study plots (30 rectangular plots of $500 \mathrm{~m}^{2}$ in each of the two stands) were selected

\begin{tabular}{|c|c|c|c|c|}
\hline & Pure stand & & Mixed stand & \\
\hline Area of parcel (ha) & 42.2 & & 34 & \\
\hline Type of soil (USDA soil survey) & Alfisols & & Inceptisols & \\
\hline Tree density in parcel (trees $\mathrm{ha}^{-1}$ ) & 266.3 & & 224.9 & \\
\hline Total standing volume in parcel $\left(\mathrm{m}^{3} \mathrm{ha}^{-1}\right)$ & 499.6 & & 463.1 & \\
\hline \multicolumn{5}{|l|}{ Standing volume per species $\left(\mathrm{m}^{3} \mathrm{ha}^{-1}\right)$} \\
\hline Fagus orientalis & 349.4 & $(70 \%)$ & 239.1 & $(52 \%)$ \\
\hline Carpinus betulus & 89.3 & $(18 \%)$ & 151.5 & $(33 \%)$ \\
\hline Acer velutinum & 36.8 & $(7 \%)$ & 35.1 & $(8 \%)$ \\
\hline Alnus subcordata & 16.3 & $(3 \%)$ & 23.0 & $(5 \%)$ \\
\hline Quercus castaneifolia & 6.1 & $(1 \%)$ & 13.8 & $(3 \%)$ \\
\hline Other species ${ }^{\mathrm{a}}$ & 1.6 & $(<1 \%)$ & 1.1 & $(<1 \%)$ \\
\hline \multicolumn{5}{|l|}{ Average proportion of beech trees on plots } \\
\hline ( $\%$ of total number of trees on plot) & $81 \%$ & & $57 \%$ & \\
\hline
\end{tabular}

${ }^{a}$ Ulmus glabra, Acer cappadocicum, Tilia begonifolia was first determined by distilling the sample with sodium hydroxide. The amount of ammonia into which $\mathrm{NH}_{4}{ }^{+}$was converted was then determined by back titration. The $\mathrm{NO}_{3}{ }^{-}$ fraction was determined using the remaining solution, into which Devarda's alloy was added to reduce $\mathrm{NO}_{3}{ }^{-}$into $\mathrm{NH}_{4}^{+}$, which in turn was analysed as described above. Phosphorus (P) was measured with a UV/V spectrophotometer (SQ-2800, US). Concentrations of potassium $\left(\mathrm{K}^{+}\right)$, calcium $\left(\mathrm{Ca}^{2+}\right)$ and magnesium $\left(\mathrm{Mg}^{2+}\right)$ were determined using a flame photometer (Abbasian et al. 2014).
We calculated monthly fluxes of $\mathrm{NO}_{3}{ }^{-}, \mathrm{NH}_{4}{ }^{+}, \mathrm{P} \mathrm{Ca}^{2+}$, $\mathrm{Mg}^{2+}$ and $\mathrm{K}^{+}$in bulk precipitation and throughfall for August 2013, November 2013, February 2014 and May 2014 by multiplying concentrations by the precipitation volume. In order to estimate fluxes on an annual scale, we further used the monthly amounts of precipitation measured at the Nowshahr meteorological station from July 2013 to June 2014 as an estimate of bulk precipitation for the months for which we had no data. To estimate throughfall volumes for the missing months, we calculated an interception factor for each season
Fig. 2 Location of the open areas and plots in pure and mixed stands of Oriental beech trees

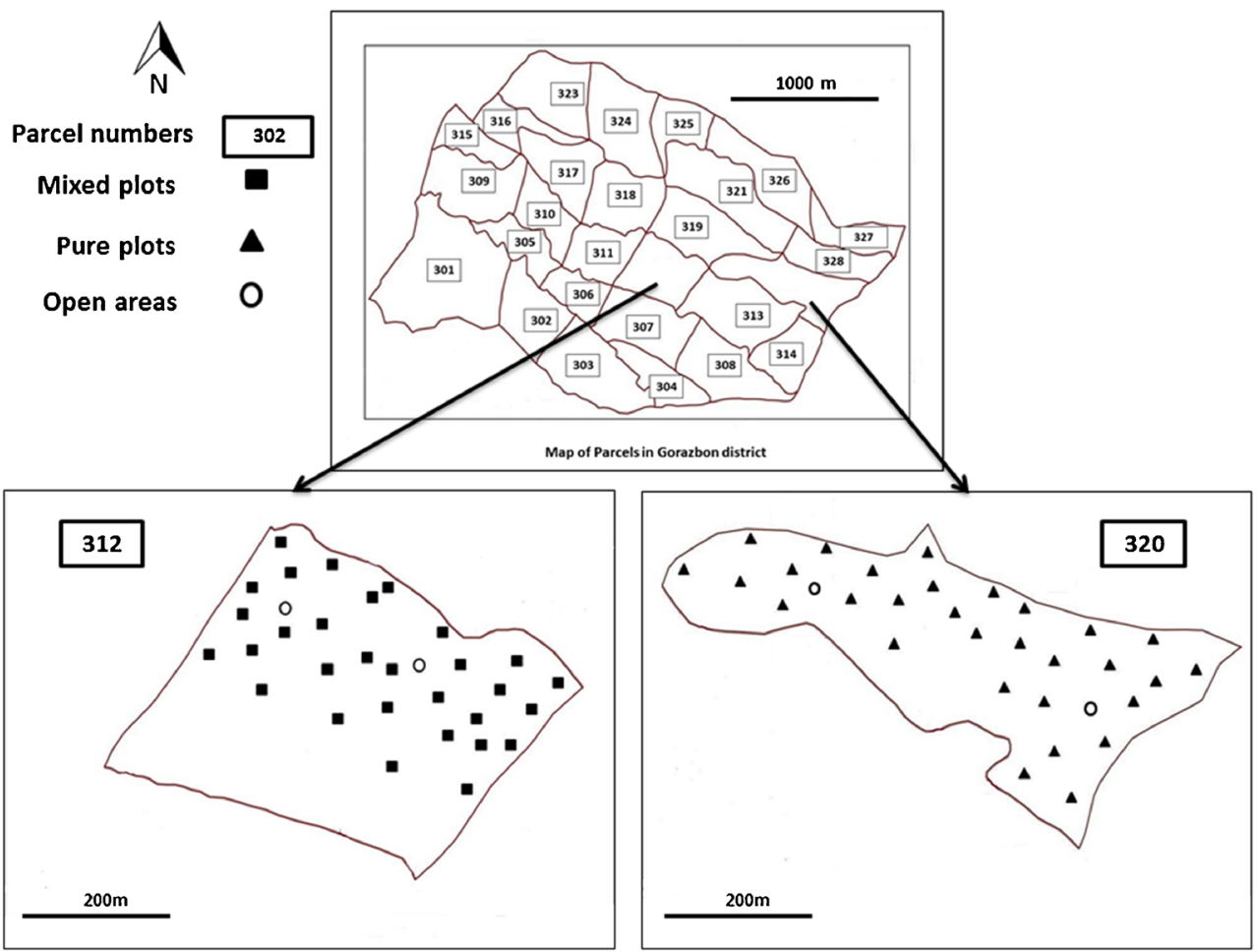


as the ratio of measured throughfall to bulk precipitation volumes and applied this factor to the bulk precipitation estimates. Within each season, the measured monthly nutrient concentrations were applied to the other 2 months for which no values were available. Measured and estimated monthly fluxes were then totalled to obtain estimates of the annual nutrient fluxes in bulk precipitation and throughfall for the period July 2013 to June 2014.

As a second estimate, given that our measurements were well distributed over the year, we extrapolated the sum of measured fluxes to annual values by simply dividing this sum by the number of measurement days and by multiplying by 365 days.

\subsection{Statistical analysis}

The normality of the variables was checked using the Kolmogorov-Smirnov test, and Levene's test was used to examine the equality of variances. The effect of stand type, season and the interactions between stand type and season were evaluated by repeated measures ANOVA. Differences between stand types and between seasons were tested using the Duncan test. For all statistical analyses, the SPSS software (version 22) was used.

\section{Results}

\subsection{Spatial variability of the open areas}

In a preliminary analysis, in order to check the comparability of the forest parcels, we assessed the spatial variability of our open areas. All four open areas showed very similar precipitation volume and chemistry. There were no significant differences between the two sets of open areas located in each of the two forest parcels (not shown).

\subsection{Quantity of bulk precipitation and throughfall}

During the period from August 2013 until May 2014, the amount of bulk precipitation was significantly higher than the amount of throughfall at the forest stands $(P<0.05$; Fig. 3$)$. Bulk precipitation amounts ranged from 56.7 in summer to $119.2 \mathrm{~mm} \mathrm{month}^{-1}$ in fall. Monthly throughfall amounts in the pure and mixed stands were higher in the dormant season compared to the growing season due to higher precipitation in the fall and winter months. They ranged from 44.4 to 84.8 in the pure stand and from 45.4 to $85.3 \mathrm{~mm} \mathrm{month}^{-1}$ in the mixed stand. Interception loss was slightly higher in the pure stand than in the mixed stand. The difference was significant $(P<$ 0.05 ) in spring, summer and winter.

\subsection{Nutrient concentrations and fluxes}

The concentrations of nutrients were generally higher in the growing season than in the dormant season, both in bulk precipitation and in throughfall (Fig. 3). In the growing season, under mixed canopy, the concentration of $\mathrm{N}$ in the form of $\mathrm{NO}_{3}{ }^{-}\left(\mathrm{NO}_{3}{ }^{-}-\mathrm{N}\right)$ was significantly higher in throughfall than in bulk precipitation, while the opposite was true for the pure stand in spring. In the dormant season, bulk precipitation showed similar or higher $\mathrm{NO}_{3}{ }^{-}-\mathrm{N}$ concentrations than throughfall. The concentration of $\mathrm{N}$ in the form of $\mathrm{NH}_{4}{ }^{+}$ $\left(\mathrm{NH}_{4}{ }^{+}-\mathrm{N}\right)$ tended to be higher than that of $\mathrm{NO}_{3}{ }^{-}-\mathrm{N}$. In the mixed stand, the $\mathrm{NH}_{4}{ }^{+}-\mathrm{N}$ concentration was significantly higher in throughfall than in bulk precipitation in spring, summer and winter. In the pure stand, the only significant difference in comparison to bulk precipitation was observed in spring, with lower $\mathrm{NH}_{4}{ }^{+}-\mathrm{N}$ in throughfall (as also observed for $\left.\mathrm{NO}_{3}{ }^{-}-\mathrm{N}\right)$. With few exceptions, $\mathrm{NO}_{3}{ }^{-} \mathrm{N}$ and $\mathrm{NH}_{4}{ }^{+}-\mathrm{N}$ concentrations were significantly higher in the mixed stand than in the pure stand (TF mixed $\geq \mathrm{TF}$ pure). $\mathrm{P}$ concentration increased after passing through the canopy. The $\mathrm{P}$ concentrations under the pure stand, under the mixed stand and in the bulk precipitation were significantly different ( $\mathrm{TF}$ mixed $>\mathrm{TF}$ pure $>\mathrm{BP}$ ). The concentrations of $\mathrm{Ca}^{2+}, \mathrm{Mg}^{2+}$ and $\mathrm{K}^{+}$followed a similar pattern of TF mixed $\geq T F$ pure $\geq B P$ in all seasons. The $\mathrm{pH}$ value of throughfall under both stands was significantly higher than in bulk precipitation in the growing season and tended to decrease from the growing season to the dormant season. The $\mathrm{pH}$ of throughfall under mixed canopy was significantly higher than under pure canopy in the growing season.

Fluxes of nutrients were generally higher in fall than in other seasons, and these peaks coincided with higher precipitation amounts (Fig. 4). This was true for all nutrients in bulk precipitation (except $\mathrm{K}^{+}$and $\mathrm{Ca}^{2+}$ ), as well as for $\mathrm{P}, \mathrm{Ca}^{2+}, \mathrm{Mg}^{2+}$ and $\mathrm{K}^{+}$in throughfall for both stands. The same pattern was apparent for $\mathrm{NO}_{3}{ }^{-}-\mathrm{N}$ and $\mathrm{NH}_{4}{ }^{+}-\mathrm{N}$; however, the differences were not always significant. The flux of $\mathrm{NO}_{3}{ }^{-}-\mathrm{N}$ tended to be higher in bulk precipitation than in throughfall in each season except in the mixed stand in summer. $\mathrm{NH}_{4}{ }^{+}-\mathrm{N}$ fluxes tended to be higher in bulk precipitation compared to throughfall in both types of stands in the dormant season and compared to throughfall in the pure stand in spring. $\mathrm{NO}_{3}{ }^{-}-\mathrm{N}$ and $\mathrm{NH}_{4}{ }^{+}-\mathrm{N}$ fluxes were generally higher under mixed canopy than under pure canopy (TF mixed $\geq \mathrm{TF}$ pure). Monthly fluxes of $\mathrm{P}, \mathrm{Mg}^{2+}, \mathrm{Ca}^{2+}$ and $\mathrm{K}^{+}$ mostly followed the order: TF mixed $\geq$ TF pure $\geq B$ P. This pattern was observed in all seasons for $\mathrm{P}$ and $\mathrm{K}^{+}$fluxes.

Our estimation of annual fluxes (Table 2) showed that although the annual throughfall amount was similar under both canopy types, throughfall fluxes of all nutrients were higher in the mixed stand than in the pure stand by approximately 5 to $40 \%$ depending on the method and the nutrient. For example, the estimated $\mathrm{N}$ fluxes varied between $<10 \mathrm{~kg}^{-1} \mathrm{ha}^{-1}$ year $^{-1}$ in the pure stand and 11 to $12 \mathrm{~kg}^{-1} \mathrm{ha}^{-1}$ year ${ }^{-1}$ in the mixed stand, 
Fig. 3 Mean $( \pm S D)$ monthly precipitation volumes and nutrient concentrations in rainfall (measured in open areas) and throughfall in pure and mixed beech stands. Different lowercase letters indicate significant $(P<0.05)$ differences among stands and different capital letters indicate significant $(P<0.05)$ differences among seasons
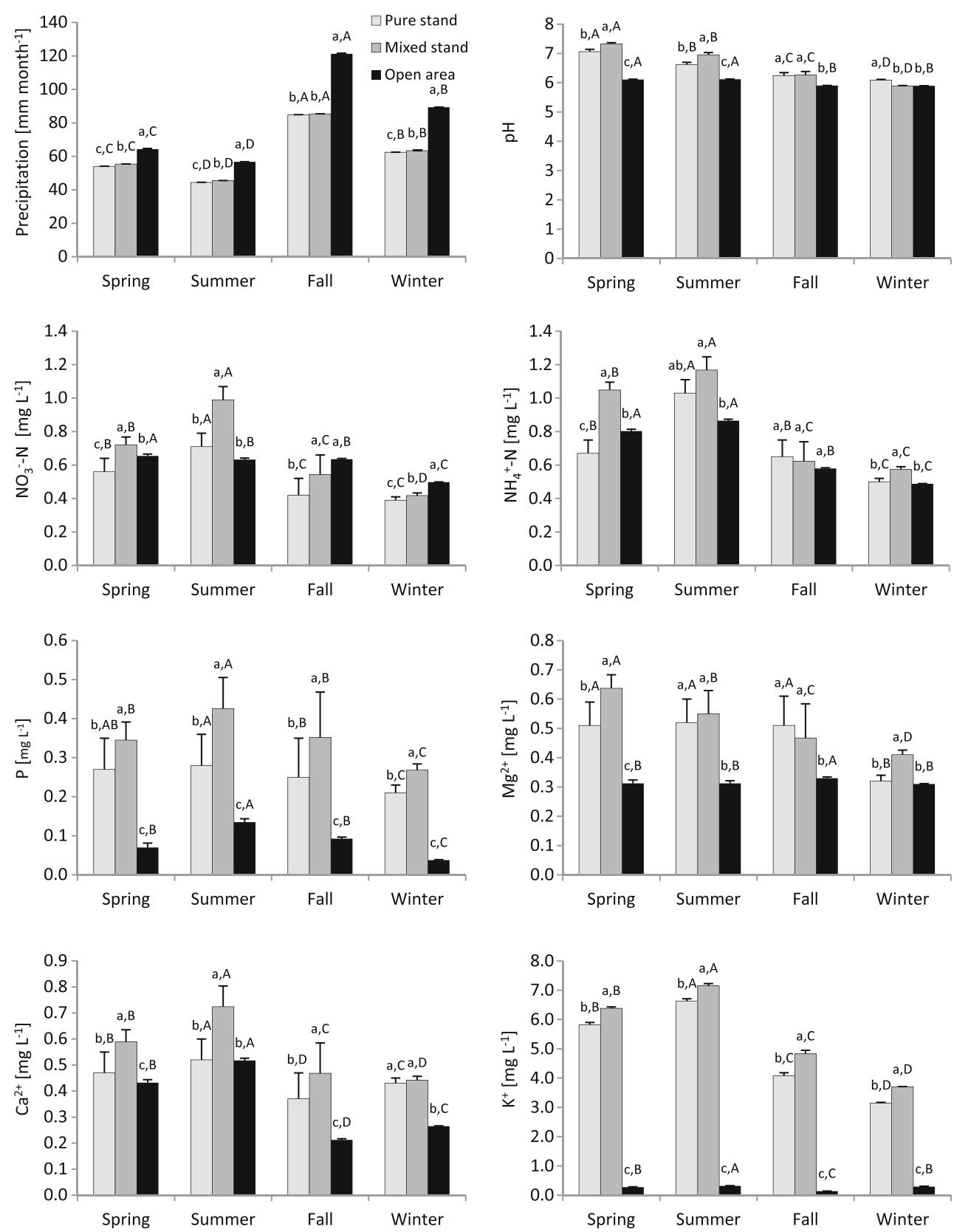

while $\mathrm{P}$ fluxes lay between $<2 \mathrm{~kg}^{-1} \mathrm{ha}^{-1}$ year $^{-1}$ in the pure stand and $>2.5 \mathrm{~kg}^{-1} \mathrm{ha}^{-1}$ year $^{-1}$ in the mixed stand. Compared to bulk precipitation fluxes, throughfall fluxes were higher except for $\mathrm{NO}_{3}{ }^{-}-\mathrm{N}$ and $\mathrm{NH}_{4}{ }^{+}-\mathrm{N}$.

\section{Discussion}

Throughfall chemistry and nutrient fluxes were investigated from August 2013 to May 2014 in pure and mixed stands of Oriental beech. To date, while considerable research has been done comparing throughfall chemistry in European beech stands, to our knowledge, there is no published study on the effect of season and degree of mixture with other species on throughfall chemistry under Oriental beech canopies.

\subsection{General effect of the tree canopy on precipitation chemistry and seasonal variation}

Our results regarding the general effect of Oriental beech canopy on precipitation chemistry and its seasonal variation are consistent with those widely found in the literature for other deciduous tree species. In our study, throughfall water was less acidic than bulk precipitation, especially in the growing season, which is due to the capacity of deciduous canopies to neutralize precipitation (Devlaeminck et al. 2005). The 
Fig. 4 Mean ( \pm SD) monthly nutrient fluxes in rainfall (measured in open areas) and throughfall in pure and mixed beech stands. Different lowercase letters indicate significant $(\mathrm{P}<$ $0.05)$ differences among stands and different capital letters indicate significant $(P<0.05)$ differences among seasons
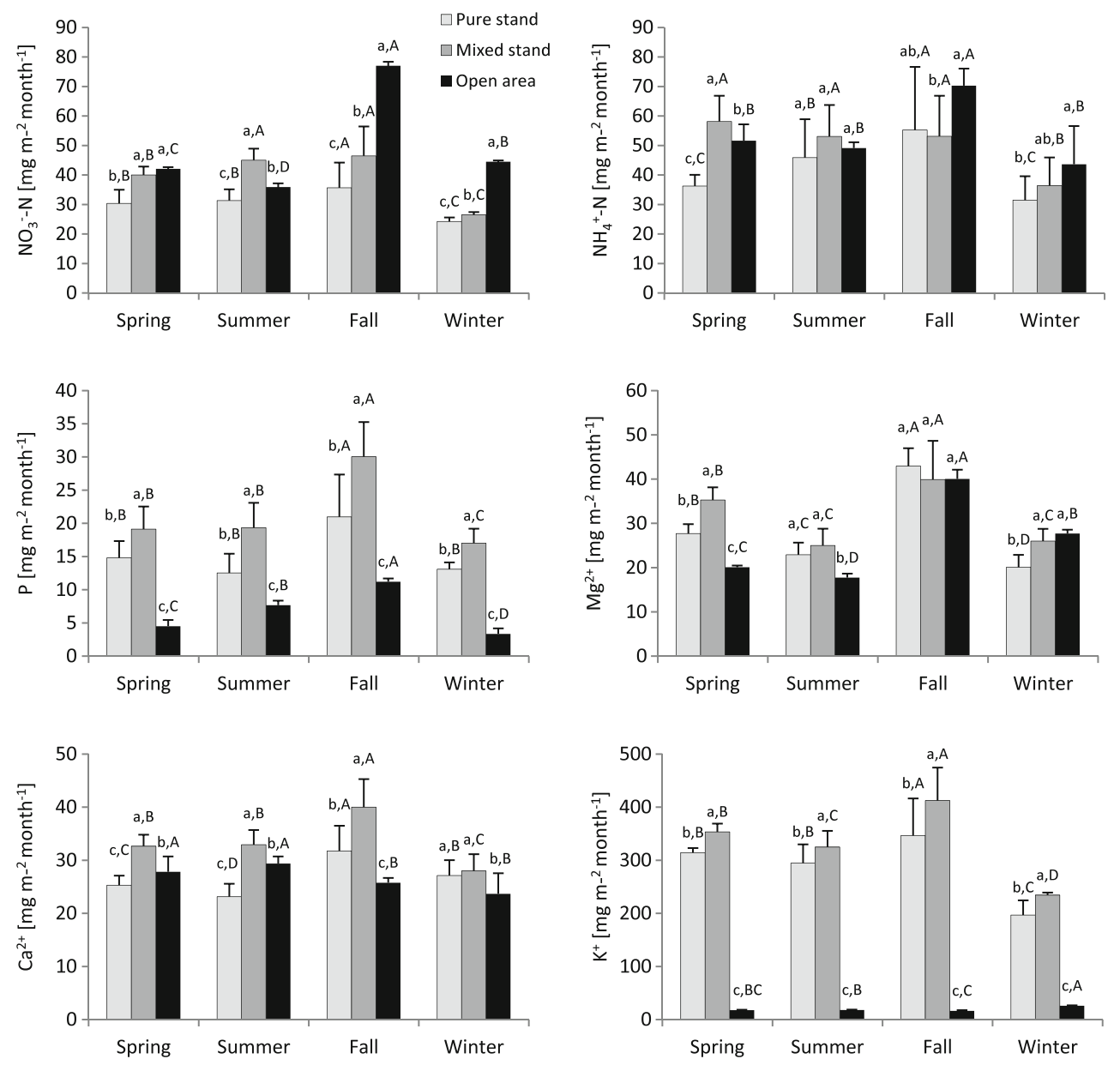

throughfall fluxes of almost all the analysed nutrients differed significantly from the bulk precipitation fluxes, both in the dormant and the growing season. These differences reflect the wash-off of dry deposited particles and the exchange with leaf surfaces (absorption and leaching; Parker 1983). The lower $\mathrm{NO}_{3}{ }^{-}$and $\mathrm{NH}_{4}{ }^{+}$concentrations and fluxes observed under canopy compared to bulk precipitation, including in the dormant season, show that these two forms of inorganic $\mathrm{N}$ were absorbed by foliage, also in the senescent stage, and by branches. Adriaenssens et al. (2011) likewise found a significant uptake of nitrogen, mostly of $\mathrm{NH}_{4}{ }^{+}$but also of $\mathrm{NO}_{3}{ }^{-}$, by the senescent leaves of European beech. Nitrogen uptake at leaf senescence was assumed by these authors to be linked to $\mathrm{N}$ retranslocation by trees (see also Houle et al. 1999). The lower $\mathrm{N}$ fluxes in throughfall compared to bulk precipitation also indicate that dry deposition of inorganic $\mathrm{N}$ compounds on foliage, in the form of gases or aerosols, is probably quite low in our study site. In many European temperate broadleaved forests, throughfall fluxes exceed bulk precipitation fluxes due to the wash-off of dry-deposited compounds
Table 2 Approximate annual precipitation $\left(\mathrm{mm}_{\mathrm{year}}{ }^{-1}\right)$ and fluxes of nutrients $\left(\mathrm{kg} \mathrm{ha}^{-1}\right.$ year $\left.^{-1}\right)$ in beech stands and in the open area for the period July 2013 to June 2014. Method 1 uses precipitation measured by the nearby Nowshahr meteorological station; method 2 extrapolates the measured values by weighting by the number of days (see text for a more detailed description)

\begin{tabular}{lccccccc}
\hline & Precipitation & $\mathrm{N}^{-N_{3}{ }^{-}}$ & $\mathrm{N}^{-N_{4}}{ }^{+}$ & $\mathrm{P}$ & $\mathrm{Mg}^{2+}$ & $\mathrm{Ca}^{2+}$ & $\mathrm{K}^{+}$ \\
\hline Method 1 & & & & & & & \\
Bulk precipitation in open area & 1114 & 6.7 & 6.7 & 0.8 & 3.5 & 3.2 & 2.3 \\
Throughfall in pure stand & 810 & 4.6 & 5.4 & 1.9 & 3.7 & 3.3 & 36.3 \\
Throughfall in mixed stand & 816 & 6.2 & 6.1 & 2.7 & 3.9 & 4.1 & 42.8 \\
Method 2 & & & & & & & \\
Bulk precipitation in open area & 1009 & 6.0 & 6.3 & 0.7 & 3.2 & 3.2 & 2.3 \\
Throughfall in pure stand & 748 & 4.0 & 5.1 & 1.8 & 3.4 & 3.1 & 35.0 \\
Throughfall in mixed stand & 758 & 5.3 & 6.0 & 2.5 & 3.8 & 3.9 & 41.7 \\
\hline
\end{tabular}


(e.g., Kristensen et al. 2004; Thimonier et al. 2005), even though $\mathrm{N}$ is most likely taken up by the canopy as well (Harrison et al. 2000).

The strongly enhanced throughfall $\mathrm{K}^{+}$concentrations and fluxes that we observed at our beech stands is also well documented in the literature for tree canopies (Stachurski and Zimka 2002). Potassium is known to be readily leached from foliage during rainwater passage (Samecka-Cymerman et al. 2010). Together with $\mathrm{Mg}^{2+}$ and $\mathrm{Ca}^{2+}, \mathrm{K}^{+}$is known to be leached especially in spring during leaf sprouting (Herrmann et al. 2006) and during leaf senescence. Phosphorus, mostly in the form of phosphate, is likewise known to be leached from the canopy (Potter et al. 1991). Accordingly, we observed higher throughfall concentrations and fluxes of this element at our plots. Our study confirms the significant effect of seasons on the nutrient input to forest soils via throughfall, which is due both to variations in bulk precipitation and to stand phenology.

\subsection{Effect of stand type (pure or mixed)}

Although our pure and mixed stands are located in two distinct forest parcels, the four open areas (two open areas in each parcel) showed highly similar rainfall volumes and chemistry, which indicates that both types of stands are subjected to the same deposition climate. Even though this was expected from the careful selection of sites with similar elevation ranges and topographies, these results confirm the comparability of the two types of stand.

In the present study, we did not measure the leaf area index of our two types of stands, which is an important stand parameter that influences the correlation between canopy cover and deposition processes (Staelens et al. 2006). However, tree density and tree volume data are good indicators of stand structure. Tree density and standing volume were slightly higher in the pure stand compared to the mixed stand at the parcel level, which is reflected by slightly higher interception losses in the pure stand. However, the differences in interception are very small (see Table 2 on the annual scale). This suggests that the differences in throughfall chemistry that we observed between pure and mixed stands are to be ascribed to differences in foliage properties (translating into, for example, different leaching or absorption rates of nutrients) rather than to differences in throughfall volumes.

The concentrations and fluxes of all nutrients were significantly higher in the mixed stands compared to the pure stands across all seasons, with few exceptions. Even though throughfall collectors were installed below the canopies of beech trees, the crown of beech trees was intertwined with that of other broadleaved species in the mixed stand. The differences between pure and mixed stands can thus be explained by differences in the foliage properties of beech trees themselves or by the influence of the other tree species.
To our knowledge, there are no studies that compare the foliage chemistry of Oriental beech to that of any of the other broadleaved species in mixture with beech as found at our sites. However, European beech trees are known to have lower foliage nutrient concentrations than European hornbeam $(C$. betulus L.) (Krauss and Heinsdorf, 2005). Furthermore, foliar analyses performed on the very beech trees under which throughfall was sampled showed that foliage concentrations of $\mathrm{N}, \mathrm{Ca}$ and $\mathrm{Mg}$ were higher in the mixed stand than in the pure stand (unpublished results). The higher foliar concentrations in the mixed stand were related to higher measured nutrient concentrations in the soil of our plots in the mixed stand compared with the pure stand, $\mathrm{P}$ being the exception (higher $\mathrm{P}$ concentrations in both beech foliage and soil in the pure stand; unpublished results). The higher throughfall nutrient fluxes observed in our mixed stand are thus likely to be related to the higher foliar concentrations in the beech trees of the mixed stand and in the other species in mixture, as well as the higher availability of nutrients in the soils under mixed canopy. Our findings are thus similar to those of Talkner et al. (2010). These authors also observed higher leaching fluxes of $\mathrm{K}^{+}, \mathrm{Mg}^{2+}$ and $\mathrm{Ca}^{2+}$ under mixed beech canopy compared to pure stands of European beech, which they related to differences in foliage and soil properties. The lower $\mathrm{N}$ throughfall fluxes in our pure stand, on the other hand, may be ascribed to a higher uptake of this element directly from precipitation, in relation to a lower $\mathrm{N}$ availability as indicated by lower foliar and soil $\mathrm{N}$ concentrations, and a higher carbon to nitrogen ratio $(\mathrm{C}: \mathrm{N})$ in the upper soil layer in the pure stand. For $\mathrm{P}$, however, the higher fluxes under mixed canopy are inconsistent with the lower $\mathrm{P}$ concentrations in the beech leaves and the soil of the mixed stand. Higher P concentration in throughfall could be related to the overlapping of canopies of different trees species in the mixed stand.

\subsection{Estimation of annual fluxes}

Using our precipitation measurements in the open areas from four separate months in the year, complemented by the precipitation measured by the Nowshahr meteorological station, we estimated an annual precipitation of $1114 \mathrm{~mm}_{\text {year }}{ }^{-1}$ for the period July 2013 to June 2014. The simple extrapolation method (weighting by the number of days) resulted in a value of $1009 \mathrm{~mm}$ year $^{-1}$. These two estimates are close to the longterm mean of $1146 \mathrm{~mm}_{\text {year }}{ }^{-1}$. Our measurement period seems therefore to be representative of a normal year in terms of precipitation, the quantity of which has been shown to be a factor in the variation in annual bulk and throughfall fluxes (e.g., Thimonier et al. 2005).

The simple extrapolation method by weighting by the number of days resulted in somewhat lower but on the whole similar fluxes (Table 2). The annual fluxes of $\mathrm{Mg}^{2+}, \mathrm{NH}_{4}{ }^{+}-\mathrm{N}$ and $\mathrm{NO}_{3}{ }^{-}-\mathrm{N}$ estimated in this study were within the range of typical values for temperate European beech forests 
(e.g., Berger et al. 2009b; Thimonier et al. 2005). Even though our estimated throughfall flux of $\mathrm{Ca}^{2+}$ was rather low in comparison to other findings in the literature, Berger et al. (2009b) found similar low values. The estimated throughfall flux of $\mathrm{K}^{+}$, on the other hand, was rather high in comparison to values in Parker (1983), Thimonier et al. (2005) and Hojjati et al. (2009). We cannot exclude the possibility that we over- or underestimated throughfall fluxes for some of the nutrients. However, the fact that our two methods resulted in quite consistent estimates indicates that these values are robust.

With about 12 to $13 \mathrm{~kg} \mathrm{ha}^{-1}$ year $^{-1}$ for bulk precipitation fluxes, 9 to $12 \mathrm{~kg} \mathrm{ha}^{-1}$ year $^{-1}$ in the forest stands, the values are within the range of empirical critical loads for nitrogen as a nutrient (10-20 kg ha ${ }^{-1}$ year $^{-1}$ for broadleaved stands; Bobbink and Hettelingh 2011). Below these values, no negative effects on sensitive parts of the ecosystem are expected to occur. The fact that the canopy visibly takes up $\mathrm{N}$ might indicate that the ecosystem is still a sink for this element.

\section{Conclusion}

The results of this study show that canopy composition in Oriental beech stands has a great effect on nutrient fluxes via throughfall. The chemistry of throughfall in pure and mixed stands appears to be influenced by differences in the foliage chemistry of beech trees themselves and possibly that of accompanying tree species, as well as by differences in soil properties among the two types of stands. Characterizing the nutrient status and fluxes for the tree species that are in mixture with Oriental beech in the Gorazbon forest would be helpful to interpret the differences between mixed and pure stands. There is also a need to investigate deposition in these stands for a longer time period in order to better estimate annual fluxes of nutrients and their year to year variability.

\begin{abstract}
Acknowledgments We would like to thank M. Jourgholami and J. Fathi at the Kheyrud research station for their coordination efforts. We are grateful to V. Etemad for his data regarding forestry information of the Kheyrud station. Thanks go to A. Nazarzadeh for his help in the laboratory. We also thank D. Pezzotta and J. Luster for their comments on laboratory methods, S. J. Alavi for statistical advice, P. Waldner for general comments and Curtis Gautschi for editing the English. This work was a part of a $\mathrm{PhD}$ thesis that was done at the University of Tehran in partnership with the Swiss Federal Institute for Forest, Snow and Landscape Research.
\end{abstract}

Funding [The internship allowing Maryam Salehi to visit the WSL as a $\mathrm{Ph} \mathrm{D}$ guest was funded by the Science Ministry of Islamic Republic of Iran.]

\section{References}

Abbasian P, Attarod P, Dolatshahi A, Sadeghi SMM (2014) Concentration, flux and enrichment of elements in Fagus orientalis in Kelardasht, north of Iran. Bull Environ Pharmacol Life Sci 3:49-52
Adriaenssens S et al (2011) Foliar nitrogen uptake from wet deposition and the relation with leaf wettability and water storage capacity. Water Air Soil Pollut 219:43-57. doi:10.1007/s11270-010-0682-8

Ahmadi MT, Attarod P, Marvi Mohadjer MR, Rahmani R, Fathi J (2009) Partitioning rainfall into throughfall, stemflow, and interception loss in an oriental beech (Fagus orientalis Lipsky) forest during the growing season. Turk J Agric For 33:557-568. doi:10.3906/tar0902-3

Beier C, Hansen K, Gundersen P (1993) Spatial variability of throughfall fluxes in a spruce forest. Environ Pollut 81:257-267. doi:10.1016/ 0269-7491(93)90208-6

Berger TW, Inselsbacher E, Mutsch F, Pfeffer M (2009a) Nutrient cycling and soil leaching in eighteen pure and mixed stands of beech (Fagus sylvatica) and spruce (Picea abies). For Ecol Manag 258:25782592. doi:10.1016/j.foreco.2009.09.014

Berger TW, Untersteiner H, Schume H, Jost G (2008) Throughfall fluxes in a secondary spruce (Picea abies), a beech (Fagus sylvatica) and a mixed spruce-beech stand. For Ecol Manag 255:605-618. doi:10. 1016/j.foreco.2007.09.030

Berger TW, Untersteiner H, Toplitzer M, Neubauer C (2009b) Nutrient fluxes in pure and mixed stands of spruce (Picea abies) and beech (Fagus sylvatica). Plant Soil 322:317-342. doi:10.1007/s11104009-9918-z

Bhat S, Jacobs JM, Bryant ML (2011) The chemical composition of rainfall and throughfall in five forest communities: a case study in Fort Benning, Georgia. Water Air Soil Pollut 218:323-332. doi:10. 1007/s11270-010-0644-1

Bobbink R, Hettelingh JP (2011) Review and revision of empirical critical loads and dose-response relationships. Coordination Centre for Effects, National Institute for Public Health and the Environment (RIVM), www.rivm.nl/cce.

Bruijnzeel LA (1989) Nutrient cycling in moist tropical forests: the hydrological framework. In: Proctor J (ed) Mineral nutrients in tropical forest and savanna ecosystems. Blackwell Scientific Publications, Oxford, pp 383-415

Carnol M, Bazgir M (2013) Nutrient return to the forest floor through litter and throughfall under 7 forest species after conversion from Norway spruce. For Ecol Manag 309:66-75. doi:10.1016/j.foreco. 2013.04.008

Chiwa M, Crossley A, Sheppard LJ, Sakugawa H, Cape JN (2004) Throughfall chemistry and canopy interactions in a Sitka spruce plantation sprayed with six different simulated polluted mist treatments. Environ Pollut 127:57-64. doi:10.1016/S0269-7491(03) 00259-8

De Schrijver A et al (2007) The effect of forest type on throughfall deposition and seepage flux: a review. Oecologia 153:663-674. doi:10.1007/s00442-007-0776-1

Devlaeminck R, De Schrijver A, Hermy M (2005) Variation in throughfall deposition across a deciduous beech (Fagus sylvatica L.) forest edge in Flanders. Sci Total Environ 337:241-252. doi: 10.1016/j.scitotenv.2004.07.005

Hansen K (1995) In-canopy throughfall measurements in Norway spruce: water flow and consequences for ion fluxes. Water Air Soil Pollut 85:2259-2264. doi:10.1007/BF01186170

Hansen K et al (2009) Litterfall and nutrient return in five tree species in a common garden experiment. For Ecol Manag 257:2133-2144. doi: 10.1016/j.foreco.2009.02.021

Harrison AF, Schulze ED, Gebauer G, Bruckner G (2000) Canopy uptake and utilization of atmospheric pollutant nitrogen. In: Schulze E-D (ed) Carbon and nitrogen cycling in European forest ecosystems, vol 142. Ecological Studies, Springer Berlin Heidelberg, pp 171-188. doi:10.1007/978-3-642-57219-7 8

Herrmann M, Pust J, Pott R (2006) The chemical composition of throughfall beneath oak, birch and pine canopies in northwest Germany. Plant Ecol 184:273-285. doi:10.1007/s11258-005-9072-5 
Hojjati SM, Hagen-Thorn A, Lamersdorf NP (2009) Canopy composition as a measure to identify patterns of nutrient input in a mixed European beech and Norway spruce forest in central Europe. Eur J For Res 128:13-25. doi:10.1007/s10342-008-0235-5

Hosseini Ghaleh Bahmani SM, Attarod P, Bayramzadeh V, Ahmadi MT, Radmehr A (2012) Throughfall, stemflow, and rainfall interception in a natural pure forest of chestnut-leaved oak (Quercus castaneifolia C.A. Mey.) in the Caspian forest of Iran. Ann For Res 55:197-206

Houle D, Ouimet R, Paquin R, Laflamme JG (1999) Interactions of atmospheric deposition with a mixed hardwood and a coniferous forest canopy at the Lake Clair Watershed (Duchesnay, Quebec). Can J For Res 29:1944-1957. doi:10.1139/x99-212

Jourgholami M, Abdi E, Chung W (2013) Decision making in forest road planning considering both skidding and road costs: a case study in the Hyrcanian forest in Iran. iForest-Biogeosci Forest 6:59-64. doi: 10.3832/efor0640-006

Krauss HH, Heinsdorf D (2005) Ernährungsstufen für wichtige Wirtschaftsbaumarten. Beitr Forstwirtsch Landschaftsökol 39:172179

Kristensen HL, Gundersen P, Callesen I, Reinds GJ (2004) Throughfall nitrogen deposition has different impacts on soil solution nitrate concentration in European coniferous and deciduous forests. Ecosyst 7:180-192. doi:10.1007/s10021-003-0216-y

Lovett GM (1994) Atmospheric deposition of nutrients and pollutants in North America: an ecological perspective. Ecol Appl 4:629-650. doi: $10.2307 / 1941997$

Mattaji A, Akef M, Kafaki SB, Hemmati V (2012) Throughfall, stemflow and canopy interception loss by oriental beech trees (Fagus orientalis Lipsky) in north forests of Iran. J Food Agric Environ 10:1183-1187

Moslehi M, Habashi H, Khormali F (2011) Effect of throughfall and forest floor leachate of beech on base cation dynamics in mixed stands. Iran J For Poplar Res 19:83-93

Parker GG (1983) Throughfall and stemflow in the forest nutrient cycle. Adv Ecol Res 13:58-135

Potter CS, Ragsdale HL, Swank WT (1991) Atmospheric deposition and foliar leaching in a regenerating southern Appalachian forest canopy. J Ecol 79:97-115

Prescott CE (2002) The influence of the forest canopy on nutrient cycling. Tree Physiol 22:1193-1200

Pretzsch $\mathrm{H}$ et al (2010) Comparison between the productivity of pure and mixed stands of Norway spruce and European beech along an ecological gradient. Ann For Sci 67:712-712. doi:10.1051/forest/ 2010037

Raat KJ, Draaijers GPJ, Schaap MG, Tietema A, Verstraten JM (2002) Spatial variability of throughfall water and chemistry and forest floor water content in a Douglas fir forest stand. Hydrol Earth Syst Sci 6: 363-374

Rahmani R, Sadoddin A, Ghorbani S (2011) Measuring and modelling precipitation components in an Oriental beech stand of the
Hyrcanian region, Iran. J Hydrol 404:294-303. doi:10.1016/j. jhydrol.2011.04.036

Rothe A, Binkley D (2001) Nutritional interactions in mixed species forests: a synthesis. Can J For Res 31:1855-1870. doi:10.1139/ cjfr-31-11-1855

Rothe A, Kreutzer K, Küchenhoff H (2002) Influence of tree species composition on soil and soil solution properties in two mixed spruce-beech stands with contrasting history in southern Germany. Plant Soil 240:47-56. doi:10.1023/A:1015822620431

Rouhi-Moghaddam E, Hosseini SM, Ebrahimi E, Tabari M, Rahmani A (2008) Comparison of growth, nutrition and soil properties of pure stands of Quercus castaneifolia and mixed with Zelkova carpinifolia in the Hyrcanian forests of Iran. For Ecol Manag 255:1149-1160. doi:10.1016/j.foreco.2007.10.048

Sagheb Talebi K, Eslami A (2008) Nature-based silviculture-how can achieve the equilibrium state in uneven-aged oriental beech stands? Proceedings of 8th IUFRO international beech symposium: 59-61

Sagheb Talebi K, Sajedi T, Yazdian F (2004) Forests of Iran. Technical Publication $\mathrm{N}^{\circ} 339$, Research Institute of Forests and Rangelands, Tehran

Samecka-Cymerman A, Kolon K, Kempers AJ (2010) Influence of Quercus robur throughfall on elemental composition of Pleurozium schreberi (Brid.) Mitt. and Hypnum cupressiforme Hedw. Pol J Environ Stud 19:763-769

Stachurski A, Zimka JR (2002) Atmospheric deposition and ionic interactions within a beech canopy in the Karkonosze Mountains. Environ Pollut 118:75-87. doi:10.1016/S0269-7491(01)00238-X

Staelens J, De Schrijver A, Verheyen K (2007) Seasonal variation in throughfall and stemflow chemistry beneath a European beech (Fagus sylvatica) tree in relation to canopy phenology. Can J For Res 37:1359-1372. doi:10.1139/X07-003

Staelens J, De Schrijver A, Verheyen K, Verhoest NEC (2006) Spatial variability and temporal stability of throughfall water under a dominant beech (Fagus sylvatica L.) tree in relationship to canopy cover. J Hydrol 330:651-662. doi:10.1016/j.jhydrol.2006.04.032

Stape JL, Binkley D, Jacob WS, Takahashi EN (2006) A twin-plot approach to determine nutrient limitation and potential productivity in Eucalyptus plantations at landscape scales in Brazil. For Ecol Manag 223:358-362. doi:10.1016/j.foreco.2005.11.015

Talkner U, Krämer I, Hölscher D, Beese FO (2010) Deposition and canopy exchange processes in central-German beech forests differing in tree species diversity. Plant Soil 336:405-420. doi:10.1007/s11104010-0491-2

Thimonier A, Schmitt M, Waldner P, Rihm B (2005) Atmospheric deposition on Swiss long-term forest ecosystem research (LWF) plots. Environ Monit Assess 104:81-118. doi:10.1007/s10661-005-1605-9

Whelan MJ, Sanger LJ, Baker M, Anderson JM (1998) Spatial patterns of throughfall and mineral ion deposition in a lowland Norway spruce (Picea abies) plantation at the plot scale. Atmos Environ 32:34933501. doi:10.1016/S1352-2310(98)00054-5 